\title{
Novel Red Cell Indices Indicating Reduced Availability of Iron are Associated With High Erythropoietin Concentration and Low pH Level in the Venous Cord Blood of Newborns
}

\author{
MARI ERVASTI, ULLA SANKILAMPI, SEPPO HEINONEN, AND KARI PUNNONEN
}

\begin{abstract}
Department of Clinical Chemistry and Hematology [M.E., K.P.], Eastern Finland Laboratory Center, Kuopio University, 70211 Kuopio, Finland; Departments of Pediatrics [U.S.], and Obstetrics and Gynecology [S.H.], Kuopio University Hospital, 70211 Kuopio, Finland
\end{abstract}

\begin{abstract}
There is evidence that an elevated erythropoietin (EPO) concentration is associated with signs of iron deficient erythropoiesis. The aim of this study was to evaluate the iron status by means of novel cellular indices and serum iron markers and to determine whether these are associated with EPO and $\mathrm{pH}$ in the venous cord blood of 193 full-term newborns. There were positive correlations between EPO and the percentage of hypochromic red blood cells (\%HYPOm) and reticulocytes (\%HYPOr) $[r=0.45(p<$ $0.001)$ and $r=0.56(p<0.001)$, respectively]. \%HYPOm and $\%$ HYPOr also had negative correlations with $\mathrm{pH}[r=-0.53$ ( $p=$ $0.001)$ and $r=-0.46(p=0.001)$, respectively]. Newborns who had low $\mathrm{pH}(\mathrm{pH} \leq 7.15, n=16)$ had significantly higher \%HYPOm, $\%$ HYPOr, and serum transferrin receptor and transferrin concentrations in their cord blood than newborns with normal $\mathrm{pH}$. Thus, in newborn cord blood, the higher number of red cells and reticulocytes with lower $\mathrm{Hb}$ content may have impaired the oxygen carrying capacity that has been a trigger for EPO production. Furthermore, signs of lower hemoglobinization of red cells are associated with low umbilical vein $\mathrm{pH}$ in the newborns, indicating an increased risk of birth asphyxia. (Pediatr Res 64: 135-140, 2008)
\end{abstract}

$\mathrm{E}^{\mathrm{n}}$ ythropoietin (EPO) is the principal hormonal stimulator of erythropoiesis, and as a response to hypoxia, EPO synthesis is stimulated via regulation by hypoxia inducible factor $1(1,2)$. EPO production occurs in the kidneys in human adults, and in fetal liver. Additionally, placental EPO production has been demonstrated in sheep (3). EPO plays some nonerythropoietic roles as well. It is needed for the normal differentiation, apoptosis and survival of neuronal cells as well as gastrointestinal tract epithelium and vascular endothelial cells $(4,5)$. Recent evidence shows that in hypoxic conditions, EPO production increases to protect brain and other tissues, and there is increasing interest in neuroprotective therapeutical approaches against hypoxic-ischemic injury $(6,7)$. Newborns who have had asphyxia after complicated or uncomplicated pregnancies are at risk for impaired neurodevelopmental outcome if EPO level, reflecting fetal hypoxemia, is increased (8). On the other hand, iron deficiency has been shown to be associated with impaired cognitive development in childhood $(9-11)$.

Received December 5, 2007; accepted March 28, 2008.

Correspondence: Mari Ervasti, M.D., Department of Clinical Chemistry and Hematology, Kuopio University, Eastern Finland Laboratory Centre, PL Post Box 1700, 70211 Kuopio, Finland; e-mail: mari.ervasti@uku.fi

This study was supported by a research grant from the Kuopio University Hospital.
Modern hematological analyzers and flow cytometric techniques make it possible to measure red blood cell (RBC) and reticulocyte features more accurately than earlier (12-14). Novel cell indices are directly measured parameters in which the size of cells and cellular $\mathrm{Hb}$ content are measured on a cell-by-cell analysis of RBC or reticulocyte populations $(12,15,16)$. Based on these measurements, the percentages of hypochromic or microcytic cells can be calculated and then used as markers of iron-deficient erythropoiesis.

Despite their potential value in diagnostics, the clinical use of these indices is still uncommon. The percentage of hypochromic RBCs (\%HYPOm) and cellular Hb content of reticulocytes $(\mathrm{CHr})$ have been established as indicators of iron status in studies on hemodialysis patients, infants, children, adolescents, blood donors, and premenopausal women (1722). In the cord blood of newborns, \%HYPOm and the percentage of hypochromic reticulocytes (\%HYPOr) are associated with both iron deficiency and higher number of immature reticulocytes (23).

We have previously shown that a higher EPO concentration might be a compensatory response to iron-deficient erythropoiesis in pregnant women at term (24). In the present study, we examined the possible association of cord blood EPO concentration with markers of iron metabolism, including the advanced cellular indices. The other objective was to determine whether umbilical blood $\mathrm{pH}$, which reflects rapid changes in oxygen delivery during labor, is affected by irondeficient erythropoiesis.

\section{SUBJECTS AND METHODS}

Subjects. The local ethics committee of the Pohjois-Savo Health Care District approved the present cross-sectional study. A total of 213 pregnant women-newborn pairs of ethnic Finnish background were enrolled during a 10-mo period in 2004-2005 at the Kuopio University Hospital $(24,25)$. The women signed informed consent forms before delivery. Venous blood samples were obtained from the women before delivery and from the cord blood

\footnotetext{
Abbreviations: CHr, cellular hemoglobin in reticulocytes; EPO, erythropoietin; GDM, gestational diabetes mellitus; hsCRP, high sensitivity C-reactive protein; \%HYPOm, percentage of hypochromic red blood cells; \%HYPOr, percentage of hypochromic reticulocytes; IRF-H, high immature reticulocyte fraction; MCHC, mean cell hemoglobin concentration; MCV, mean cell volume of red blood cells; MCVr, mean cell volume of reticulocytes; RBC, red blood cell; TfR, transferrin receptor; TfR-F Index, transferrin receptor/ $\log ($ ferritin); TfSat, transferrin saturation
} 
of their 193 full-term newborns (gestational age 37 wk or more). These women and infants comprised the study population.

The study population included a subgroup of 67 newborns considered to have clinical signs of birth asphyxia (e.g., abnormal CTG, infection, low Apgar score, abnormal placenta, growth retardation). Therefore, the midwife in charge decided that their umbilical blood $\mathrm{pH}$ should be analyzed after cord clamping. Cord blood sample for $\mathrm{pH}$ was not obtained in normal term vaginal deliveries with an entirely normal outcome.

Data on maternal characteristics and pregnancy outcome were obtained from the birth register of Kuopio University Hospital. These data included pregnancy complications, mode of delivery, gestational age, birth weight and length, placental weight, and Apgar score (at one and five minutes of age). Gestational age was calculated from the beginning of the last menstruation unless an ultrasonography exam in the first trimester had demonstrated a discrepancy of $>3$ d. Relative placental size (ratio of placental weight to birth weight) was calculated.

Laboratory Analyses. Venous blood was collected from the pregnant women before delivery, and from venous cord blood by needle puncture after cord clamping in EDTA tubes (Vacutainer, Becton Dickinson Vacutainer Systems, Plymouth, UK). The complete blood count including novel RBC and reticulocyte indices, such as \%HYPOm, \%HYPOr, and $\mathrm{Hb}$ content of RBCs or $\mathrm{CHr}$, was analyzed within $6 \mathrm{~h}$ on the Advia 120 Hematology System (Bayer Diagnostics Co., Tarrytown, NY).

The samples for serum examinations were collected in $6 \mathrm{~mL}$ serum tubes (Vacutainer), and the serum was separated and stored frozen at $-20^{\circ} \mathrm{C}$. Serum iron was measured on a Konelab 60i unit (Thermo Fisher Scientific, Vantaa, Finland). Transferrin was analyzed using an Immage analyzer (Beckman Coulter Inc., Fullerton, CA). Serum soluble transferrin receptor (TfR) was measured using an automated immunoturbidometric IDeA TfR-IT assay (Orion Diagnostica, Espoo, Finland) with a Konelab 60i unit (Thermo Fisher Scientific). Serum EPO, ferritin and high sensitivity C-reactive protein (hsCRP) concentrations (Diagnostic Products Corporation, Los Angeles, CA) were measured by commercial kits using an automated Immulite2000 analyzer (IEMA) (Diagnostic Products Corporation). Transferrin saturation (TfSat) was calculated using the formula [S-Iron $(\mu \mathrm{mol} / \mathrm{L}) \times 0.038] / \mathrm{S}-$ Transferrin (g/L)*100 and the TfR-F Index was defined as TfR/ LogFerritin. In case of suspected birth asphyxia, blood was drawn into 1 mL syringe and analyzed immediately using Rapidlab 1265 (Bayer Health Care, Tarrytown, NY).

The total coefficient variation $(\mathrm{CV} \%)$ for the cell indices used are as follows: $\mathrm{Hb} 1.0 \%$, hematocrit $1.0 \%$, RBC count $1.0 \%$, proportion of reticulocytes $4.0 \%$, high immature reticulocyte fraction (IRF-H) $7.0 \%$, mean cell volume of RBCs (MCV) 1.0\%, mean cell volume of reticulocytes (MCVr) $1.0 \%$, mean cell $\mathrm{Hb} 1.0 \%$, mean cell $\mathrm{Hb}$ concentration (MCHC) $1.0 \%$, $\%$ HYPOm $5.0 \%$, \%HYPOr $4.0 \%$, cellular $\mathrm{Hb}$ content of RBCs $1.0 \%$, CHr $1.0 \%$. The total CV\% for serum measurements are as follows: hsCRP $8.7 \%$, ferritin $4.0 \%$, EPO $5.7 \%$, TfR $13.1 \%$, iron $6.3 \%$ and transferrin $12.0 \%$.

Statistical Analyses. The main outcome measurements were venous umbilical blood EPO concentration and, in the subgroup of potentially asphyxiated newborns $(n=67)$, the venous umbilical $\mathrm{pH}$. For the analyses of the associations between iron parameters, obstetric data, and EPO concentration, the 193 study subjects were divided into subgroups on the basis of EPO concentration quartiles. The statistical significance of differences between the lowest and highest EPO quartile groups was tested by the Mann-Whitney $U$ test. In the case of categorical variables, the significance of differences was tested with the $\chi^{2}$ test.

The relationships between EPO concentration, iron parameters, and obstetric data and the newborn umbilical vein $\mathrm{pH}$ were also assessed in the group of 67 newborns who were suspected of having signs of asphyxia and therefore had their umbilical $\mathrm{pH}$ measured. These infants were divided into two groups based on $\mathrm{pH} \leq 7.15$ (low $\mathrm{pH}, n=16$ ) or $\mathrm{pH}>7.15$ (normal $\mathrm{pH}, n=51$ ) (26). Infants in these two groups were also compared with those with "no clinical signs of asphyxia" ( $\mathrm{pH}$ not analyzed, $n=126)$. For the comparison of differences between the low and normal $\mathrm{pH}$ groups, the Mann-Whitney $U$ test was used. The Spearman correlation test was used for calculating the associations between cellular and serum iron status parameters, and EPO concentration, or $\mathrm{pH}$ level. The blood count and serum iron status measurements of the pregnant women were used to analyze the possible effects of maternal parameters on the newborn cord blood EPO or $\mathrm{pH}$, and this was tested by the Spearman correlation test.

Cord blood $\mathrm{Hb}$ below $145 \mathrm{~g} / \mathrm{L}$ was used as a definition for anemia (27). Iron deficiency in a newborn was defined as cord blood TfSat below $30 \%$ (27). Statistical significance was defined as $p<0.05$. Microsoft Excel 2000 for Windows (Microsoft Office, Microsoft Corp., Redmond, WA) and SPSS 11.5 for Windows (SPSS Inc., Chicago, IL) were used as statistical software. The figures were produced with the GraphPad Prism 4.0 for Windows (GraphPad Software Inc., San Diego, CA).
Table 1. Obstetric background data of the 193 newborns

\begin{tabular}{|c|c|c|c|}
\hline Variable & \multicolumn{3}{|c|}{ All newborns $(n=193), n(\%)$} \\
\hline Males & \multicolumn{3}{|c|}{$106(55 \%)$} \\
\hline \multicolumn{4}{|l|}{ Mode of delivery } \\
\hline Vaginal delivery & \multicolumn{3}{|c|}{$150(78 \%)$} \\
\hline $\begin{array}{l}\text { Elective Caesarean } \\
\text { section }\end{array}$ & \multicolumn{3}{|c|}{$24(12 \%)$} \\
\hline $\begin{array}{l}\text { Emergency Caesarean } \\
\text { section }\end{array}$ & \multicolumn{3}{|c|}{$19(10 \%)$} \\
\hline \multicolumn{4}{|l|}{ Asphyxia group } \\
\hline $\begin{array}{l}\text { No signs of birth } \\
\text { asphyxia (No need for } \\
\text { pH measurement) }\end{array}$ & \multicolumn{3}{|c|}{$126(65 \%)$} \\
\hline Normal pH $(>7.15)$ & \multicolumn{3}{|c|}{$51(26 \%)$} \\
\hline Low $\mathrm{pH}(\leq 7.15)$ & \multicolumn{3}{|c|}{$16(8 \%)$} \\
\hline \multicolumn{4}{|l|}{ Maternal conditions } \\
\hline $\begin{array}{l}\text { Gestational diabetes } \\
\text { mellitus }\end{array}$ & \multicolumn{3}{|c|}{$24(12 \%)$} \\
\hline Gestational hypertension & \multicolumn{3}{|c|}{$7(4 \%)$} \\
\hline Pre-eclampsia & \multicolumn{3}{|c|}{$4(2 \%)$} \\
\hline \multirow[t]{2}{*}{ Liver dysfunction } & \multicolumn{3}{|c|}{$2(1 \%)$} \\
\hline & 10 th & Median & 90 th \\
\hline Gestational age (weeks) & 38.4 & 40.1 & 41.7 \\
\hline Birth weight $(\mathrm{g})$ & 2990 & 3620 & 4205 \\
\hline Placental weight (g) & 480 & 600 & 750 \\
\hline Relative placental size & 0.143 & 0.170 & 0.203 \\
\hline Apgar score $1 \mathrm{~min}$ & 8.0 & 9.0 & 9.0 \\
\hline Apgar score $5 \mathrm{~min}$ & 8.0 & 9.0 & 9.0 \\
\hline
\end{tabular}

Relative placental size is defined by placental weight to birth weight ratio.

\section{RESULTS}

Associations of obstetric data and cord blood iron status with EPO concentration. The obstetric data and characteristics of all the newborns $(n=193)$ are shown in Table 1. Mode of delivery was associated with the cord blood EPO concentration. The EPO concentrations were significantly higher in newborns delivered by emergency section (n, median, 10th and 90th centiles) $(n=19,34.6,11.4$ and $183.0 \mathrm{mIU} / \mathrm{mL})$ or vaginally $(n=150,27.8,13.8$ and $83.1 \mathrm{mIU} / \mathrm{mL})$ than in newborns who were delivered by an elective cesarean section $(n=24,20.5,12.1$ and $44.2 \mathrm{mIU} / \mathrm{mL}$ ) (Mann-Whitney $U$ tests, $p=0.011$ and 0.012 , respectively).

In the highest EPO quartile group, an elective cesarean section was significantly less common than in the lowest EPO quartile group ( 2 versus 19\%, $p=0.015, \chi^{2}$ test); however, the frequency of vaginal deliveries and emergency sections did not differ between the groups of highest or lowest EPO quartiles. Pregnancy complications did not differ between the highest and the lowest EPO groups. Additionally, there were no statistically significant differences (Mann-Whitney $U$ ) in birth weight, placental weight, relative placental size, gender, or Apgar scores (at one and five minutes) between the highest and the lowest EPO quartile groups. Neither maternal blood count (including aforementioned indices) nor maternal serum iron status measurements correlated with cord blood EPO concentration or $\mathrm{pH}$ level (data not shown).

Descriptive statistics of all the newborns showed wide variation in cellular and serum iron status parameters (Table 2). Cord blood iron status measurements in the lowest and the highest EPO quartile groups are shown in Table 2. 
Table 2. Iron status measurements in the venous cord blood of all 193 newborns and in the erythropoietin (EPO) concentration quartile

\begin{tabular}{|c|c|c|c|c|c|c|c|c|c|c|}
\hline \multirow[b]{3}{*}{ Variable } & \multicolumn{9}{|c|}{ groups } & \multirow[b]{3}{*}{$p$} \\
\hline & \multicolumn{3}{|c|}{ All newborns $(n=193)$} & \multicolumn{3}{|c|}{ Highest EPO quartile $(n=48)$} & \multicolumn{3}{|c|}{ Lowest EPO quartile $(n=48)$} & \\
\hline & 10th & Median & 90th & 10th & Median & 90th & 10th & Median & 90th & \\
\hline \multicolumn{11}{|l|}{ Blood count } \\
\hline $\mathrm{Hb}(\mathrm{g} / \mathrm{L})$ & 138 & 160 & 180 & 138 & 163 & 181 & 138 & 161 & 179 & 0.107 \\
\hline Erythrocytes $\left(\times 10^{12}\right.$ cells $\left./ \mathrm{L}\right)$ & 3.89 & 4.52 & 5.04 & 3.99 & 4.58 & 5.19 & 3.90 & 4.54 & 5.13 & 0.408 \\
\hline $\mathrm{HCT}(\mathrm{L} / \mathrm{L})$ & 0.42 & 0.49 & 0.56 & 0.44 & 0.52 & 0.57 & 0.42 & 0.50 & 0.54 & 0.012 \\
\hline $\mathrm{MCV}(\mathrm{fL})$ & 104 & 109 & 115 & 108 & 112 & 117 & 103 & 107 & 113 & $<0.001$ \\
\hline $\mathrm{MCHC}(\mathrm{g} / \mathrm{L})$ & 312 & 324 & 336 & 306 & 319 & 332 & 320 & 329 & 338 & $<0.001$ \\
\hline$\%$ Retic $(\%)$ & 2.9 & 3.9 & 5.1 & 3.0 & 4.3 & 5.3 & 2.9 & 3.8 & 5.1 & 0.057 \\
\hline IRF-H (\%) & 14.4 & 23.2 & 33.6 & 18.6 & 26.2 & 38.1 & 10.3 & 22.0 & 29.6 & 0.002 \\
\hline $\mathrm{CHm}(\mathrm{pg})$ & 33.1 & 34.8 & 36.6 & 33.6 & 35.0 & 36.6 & 33.3 & 34.8 & 36.7 & 0.687 \\
\hline $\mathrm{CHr}(\mathrm{pg})$ & 34.0 & 35.5 & 37.3 & 34.0 & 35.6 & 37.3 & 34.2 & 35.5 & 37.1 & 0.605 \\
\hline Ferritin $(\mu \mathrm{g} / \mathrm{L})$ & 74 & 166 & 336 & 47 & 142 & 305 & 77 & 167 & 325 & 0.190 \\
\hline TfR-F Index & 0.58 & 0.86 & 1.37 & 0.8 & 1.1 & 2.1 & 0.5 & 0.8 & 1.1 & $<0.001$ \\
\hline Iron $(\mu \mathrm{mol} / \mathrm{L})$ & 18.6 & 27.0 & 37.6 & 14.8 & 22.2 & 37.8 & 21.2 & 28.2 & 37.4 & 0.002 \\
\hline Transferrin $(\mathrm{g} / \mathrm{L})$ & 1.54 & 1.93 & 2.44 & 1.68 & 2.13 & 2.76 & 1.41 & 1.78 & 2.31 & $<0.001$ \\
\hline TfSat $(\%)$ & 35 & 55 & 79 & 23 & 41 & 64 & 39 & 58 & 84 & $<0.001$ \\
\hline hsCRP (mg/L) & 0.09 & 0.10 & 0.25 & 0.09 & 0.14 & 0.35 & 0.09 & 0.10 & 0.20 & 0.024 \\
\hline
\end{tabular}

$\mathrm{Hb}$ indicates hemoglobin; HCT, hematocrit; MCV, mean cell volume of red blood cells; MCVr, mean cell volume of reticulocytes; MCH, mean cell hemoglobin; MCHC, mean cell hemoglobin concentration; \%Retic, proportion of reticulocytes; IRF-H, high immature reticulocyte fraction; CHm, cellular hemoglobin in red blood cells; CHr, cellular hemoglobin in reticulocytes; \%HYPOm, percentage of hypochromic red blood cells; \%HYPOr, percentage of hypochromic reticulocytes; TfR, transferrin receptor; TfR-F Index, transferrin receptor/Log(ferritin); TfSat, transferrin saturation; hsCRP, high sensitivity C-reactive protein. $p$ value is the significance of the differences between the highest and lowest EPO quartiles using Mann-Whitney-U test.

Table 3. The Spearman correlations between umbilical cord blood erythropoietin $(E P O)(n=193)$ or $\mathrm{pH}(n=67)$, and iron status measurements in newborns

\begin{tabular}{|c|c|c|c|c|}
\hline & \multicolumn{2}{|c|}{$\begin{array}{c}\text { Cord blood EPO } \\
v s . \text { iron status } \\
\text { measurements }\end{array}$} & \multicolumn{2}{|c|}{$\begin{array}{l}\text { Cord blood } \mathrm{pH} \\
\text { vs. iron status } \\
\text { measurements }\end{array}$} \\
\hline & $\begin{array}{c}\text { Correlation } \\
\text { coefficient }\end{array}$ & $p$ & $\begin{array}{c}\text { Spearman's } \\
\text { rho }\end{array}$ & $p$ \\
\hline \multicolumn{5}{|l|}{ Blood count } \\
\hline $\mathrm{Hb}$ & 0.086 & 0.234 & -0.194 & 0.116 \\
\hline Erythrocytes & 0.014 & 0.845 & -0.198 & 0.107 \\
\hline HCT & 0.148 & 0.040 & -0.308 & 0.011 \\
\hline $\mathrm{MCV}$ & 0.372 & $<0.001$ & -0.355 & 0.003 \\
\hline $\mathrm{MCVr}$ & 0.504 & $<0.001$ & -0.288 & 0.018 \\
\hline $\mathrm{MCH}$ & 0.122 & 0.090 & -0.011 & 0.928 \\
\hline $\mathrm{MCHC}$ & -0.318 & $<0.001$ & 0.451 & $<0.001$ \\
\hline$\%$ Retic & 0.160 & 0.026 & 0.090 & 0.469 \\
\hline IRF-H & 0.246 & 0.001 & -0.414 & $<0.001$ \\
\hline $\mathrm{CHm}$ & 0.092 & 0.204 & 0.090 & 0.468 \\
\hline $\mathrm{CHr}$ & 0.076 & 0.292 & 0.099 & 0.423 \\
\hline$\% \mathrm{HYPOm}$ & 0.453 & $<0.001$ & -0.525 & $<0.001$ \\
\hline \%HYPOr & 0.560 & $<0.001$ & -0.457 & $<0.001$ \\
\hline \multicolumn{5}{|c|}{ Serum measurements } \\
\hline EPO & - & & -0.375 & 0.002 \\
\hline $\mathrm{TfR}$ & 0.419 & $<0.001$ & -0.429 & $<0.001$ \\
\hline Ferritin & -0.109 & 0.131 & 0.050 & 0.687 \\
\hline TfR-F Index & 0.403 & $<0.001$ & -0.372 & 0.002 \\
\hline Iron & -0.284 & $<0.001$ & -0.011 & 0.928 \\
\hline Transferrin & 0.314 & $<0.001$ & -0.375 & 0.002 \\
\hline TfSat & -0.436 & $<0.001$ & 0.227 & 0.067 \\
\hline hsCRP & 0.208 & 0.004 & -0.246 & 0.046 \\
\hline
\end{tabular}

Abbreviations are explained in Table 2.
Iron deficiency was rare among the newborns, only nine of them having TfSat below $30 \%$. A total of 38 newborns had $\mathrm{Hb}$ below $145 \mathrm{~g} / \mathrm{L}$, indicating anemia. Even though the mean $\mathrm{Hb}$ level did not differ, the infants in the highest EPO quartile group had signs of poorer iron status than those in the lowest EPO quartile. This was seen both in the traditional red cell indices (higher MCV, and lower MCHC in the highest EPO group), and in the advanced red cell indices (higher \%HYPOr, \%HYPOm, MCVr and IRF-H in the highest EPO group). The same was true for the serum markers (higher TfR, TfR-F Index and transferrin and lower iron and TfSat in those in the highest EPO quartile) (Table 2). This observation was confirmed in the correlation analysis between EPO concentration and iron status measurements (Table 3). Although the EPO level had some dependency on the mode of delivery, the correlations were found to be in a similar linear fashion in all delivery groups (Figure 1).

Newborns of mothers with gestational diabetes mellitus (GDM) had significantly higher birth weight $(p=0.018)$ and $\operatorname{MCV}(p=0.018)$ and significantly lower ferritin $(p=0.025)$ than those without maternal GDM (Mann-Whitney $U$ test, data not shown). EPO, $\mathrm{pH}$, and other cellular or serum iron status measurements were comparable in infants with or without maternal GDM. As the numbers of women with preeclampsia, hypertension, or liver dysfunction were low (Table 1), detailed statistical analyses were not carried out for them.

Association of iron status measurements with venous cord blood pH. The cord blood $\mathrm{pH}$ was analyzed in 67 infants who 

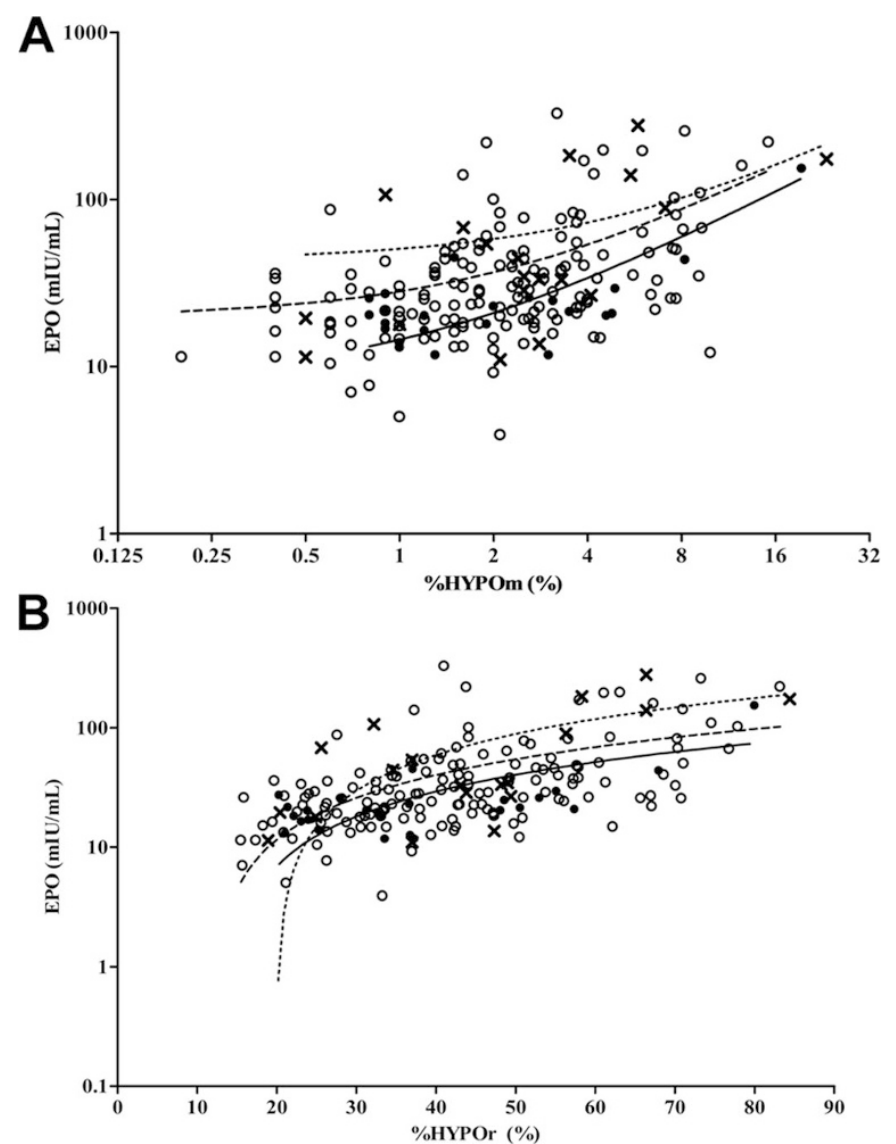

Figure 1. Scatter plots between cord blood erythropoietin (EPO) concentration and A) percentage of hypochromic red blood cells (\%HYPOm) and B) reticulocytes (\%HYPOr) in 193 full-term newborns. The curves in the figures are linear regression lines. Note the Log scales. X and the dotted line indicate newborns born by an emergency section; $\bigcirc$ and the dash line indicate newborns born by vaginal delivery; $\bullet$ and the solid line shows newborns born by an elective cesarean section.

were considered to have signs of birth asphyxia. Fifty-one of them had $\mathrm{pH}>7.15$ (normal $\mathrm{pH}$ ) and 16 had $\mathrm{pH} \leq 7.15$ (low $\mathrm{pH}$ ). The lowest $\mathrm{pH}$ was 7.00 , and the lowest 1 and $5 \mathrm{~min}$ Apgar scores were 4 and 7, indicating that in reality, none of the newborns suffered from severe birth asphyxia. Among the 67 newborns, the $\mathrm{pH}$ did not differ significantly in those born vaginally or by elective or emergency cesarean section (Mann-Whitney $U$ test, $p>0.112$ for all comparisons).

Data on cellular and serum iron status measurements and EPO concentrations in normal and low $\mathrm{pH}$ groups are compared in Table 4. The results of the 126 infants without signs of asphyxia are shown as well, and their results closely resembled those in the infants with normal $\mathrm{pH}$, as shown in Table 4 . Hb levels were similar in those newborns with normal or low $\mathrm{pH}$. Cord blood EPO concentration was significantly higher in the low $\mathrm{pH}$ group ( $p=0.002$, Mann-Whitney $U$ test). Signs of decreased iron availability, e.g., significantly higher \%HYPOm, \%HYPOr, TfR, and TfR-F index as well as lower MCHC, were seen in the low $\mathrm{pH}$ group than in those with normal $\mathrm{pH}$. Indirect signs of increased erythropoietic activity were seen in newborns in the low $\mathrm{pH}$ group, as their IRF-H, MCV, and $\mathrm{MCVr}$ were higher than in the normal $\mathrm{pH}$ group. These observations were confirmed by the significant negative correlations between umbilical blood
$\%$ HYPOm, \%HYPOr, TfR, TfR-Index versus $\mathrm{pH}$ (Table 3). Furthermore, low $\mathrm{pH}(\leq 7.15)$ was significantly more common in the highest than in the lowest EPO quartile group (21 versus $0 \%$, $p=0.002, \chi^{2}$ test), but the groups of "no signs of" or normal $\mathrm{pH}$ were similarly found in both the lowest and the highest EPO quartiles (Table 1).

\section{DISCUSSION}

The findings of this study suggest that in newborn cord blood, a higher EPO concentration may be a compensatory response to fetal iron-deficient erythropoiesis, as evidenced by the higher number of hypochromic RBCs and reticulocytes because of lower hemoglobinization. A possible explanation for this observation is that, even in the absence of clinical anemia, hypochromic cells do not carry as much oxygen as normochromic cells, thus resulting in imminent tissue hypoxia and risk of birth asphyxia. This is consistent with findings of our recent study, in which we found that maternal EPO concentration is associated with coordinated changes in cellular indices, reflecting a lower availability of iron and thus impaired oxygen delivery by RBCs (24).

In uncomplicated pregnancies, labor has been shown to increase the EPO concentration in the newborn (28). In the present study, those infants born by elective cesarean section, i.e., without labor stress, had lower EPO values than those born after labor stress. However, higher EPO levels were found in all delivery groups among those newborns who had $\mathrm{RBCs}$ with the lowest $\mathrm{Hb}$ contents. Thus, EPO production may be elevated as a response to acute hypoxic distress intrapartum, or as a response to prolonged stress during pregnancy due to placental insufficiency, for example (29).

In fetuses with hemolytic anemia and $\mathrm{Rh}$ immunization, extremely low $\mathrm{Hb}$ has been found to be associated with a high EPO level $(30,31)$. However, no significant correlation between $\mathrm{EPO}$ and $\mathrm{Hb}$ has been found in healthy term newborns with normal $\mathrm{Hb}$ concentrations, as is the case in this study $(29,32)$. Cellular indices measured by flow cytometry may be a more sensitive method for analyzing subtle changes in iron availability in newborns. When we measured cell indices reflecting minor changes in cellular $\mathrm{Hb}$ contents, we found that EPO production may be triggered by a minor decrease in the $\mathrm{Hb}$ content of RBCs and reticulocytes in the fetus. Hence, not only the mass but also the quality of cells affects the oxygen carrying capacity.

Cellular indices show coordinated changes when iron is not sufficiently available for erythropoiesis, already before anemia (17-20). Although \%HYPOm and \%HYPOr may be influenced by increased erythropoietic activity in newborns, they are also dependent on iron status (23). Similarly, an elevated $\mathrm{RBC}$ zinc protoporphyrin in the cord blood at birth has been found to be associated with increased erythropoiesis (33). In addition to the availability of iron, other factors may lead to increased EPO production. Placental insufficiency may intermittently reduce the delivery of oxygen to fetal tissues and thus gradually lead to elevated fetal EPO concentration and enhanced erythropoiesis. This may in turn be seen as higher $\mathrm{MCV}$ and MCVr, and also slightly in the reticulocyte count. 
Table 4. The iron status measurements of 193 newborns in the asphyxia groups

\begin{tabular}{|c|c|c|c|c|c|c|c|c|c|c|}
\hline \multirow[b]{2}{*}{ Variable } & \multicolumn{3}{|c|}{$\begin{array}{l}\text { No clinical signs of asphyxia } \\
\text { (no need for } \mathrm{pH})(n=126)\end{array}$} & \multicolumn{3}{|c|}{ Normal $\mathrm{pH}(>7.15)(n=51)$} & \multicolumn{3}{|c|}{ Low $\mathrm{pH}(\leq 7.15)(n=16)$} & \multirow[b]{2}{*}{$p$} \\
\hline & 10th & Median & 90th & 10th & Median & 90th & 10th & Median & 90th & \\
\hline \multicolumn{11}{|l|}{ Acid-base analysis } \\
\hline Umbilical cord blood $\mathrm{pH}$ & & - & & 7.19 & 7.28 & 7.41 & 7.02 & 7.11 & 7.15 & $<0.001$ \\
\hline \multicolumn{11}{|l|}{ Blood count } \\
\hline $\mathrm{Hb}(\mathrm{g} / \mathrm{L})$ & 138 & 161 & 178 & 142 & 160 & 181 & 131 & 161 & 190 & 0.895 \\
\hline Erythrocytes $\left(\times 10^{12}\right.$ cells/L) & 3.90 & 4.50 & 5.04 & 3.84 & 4.52 & 5.07 & 3.72 & 4.60 & 5.12 & 0.757 \\
\hline $\mathrm{HCT}(\mathrm{L} / \mathrm{L})$ & 0.42 & 0.49 & 0.56 & 0.43 & 0.48 & 0.56 & 0.43 & 0.53 & 0.58 & 0.190 \\
\hline $\operatorname{MCV}(\mathrm{fl})$ & 104 & 109 & 115 & 104 & 109 & 115 & 106 & 114 & 120 & 0.006 \\
\hline $\operatorname{MCVr}(\mathrm{fl})$ & 117 & 123 & 132 & 118 & 124 & 130 & 120 & 128 & 139 & 0.035 \\
\hline $\mathrm{MCH}(\mathrm{pg})$ & 34 & 35 & 37 & 34 & 35 & 37 & 33 & 35 & 38 & 0.680 \\
\hline $\mathrm{MCHC}(\mathrm{g} / \mathrm{L})$ & 314 & 324 & 338 & 314 & 327 & 336 & 303 & 311 & 330 & $<0.001$ \\
\hline$\%$ Retic $(\%)$ & 2.9 & 3.9 & 5.1 & 3.1 & 4.1 & 5.1 & 2.9 & 3.7 & 4.8 & 0.289 \\
\hline IRF-H (\%) & 14.4 & 23.2 & 33.5 & 13.5 & 22.3 & 31.3 & 22.0 & 29.8 & 40.5 & $<0.001$ \\
\hline $\mathrm{CHm}(\mathrm{pg})$ & 33.0 & 34.8 & 36.7 & 33.3 & 34.8 & 36.5 & 32.7 & 34.6 & 36.6 & 0.435 \\
\hline $\mathrm{CHr}(\mathrm{pg})$ & 34.0 & 35.5 & 37.3 & 34.0 & 35.5 & 37.3 & 33.6 & 35.6 & 37.0 & 0.612 \\
\hline \%HYPOm (\%) & 0.7 & 1.9 & 6.1 & 0.8 & 2.4 & 4.8 & 1.5 & 6.4 & 13.3 & $<0.001$ \\
\hline$\%$ HYPOr $(\%)$ & 23.5 & 38.0 & 59.8 & 21.1 & 41.7 & 62.6 & 33.3 & 61.5 & 76.3 & $<0.001$ \\
\hline \multicolumn{11}{|l|}{ Serum measurements } \\
\hline EPO (mIU/mL) & 13.0 & 25.7 & 66.5 & 13.1 & 25.7 & 143.8 & 24.0 & 65.7 & 231.0 & 0.002 \\
\hline TfR (mg/L) & 1.4 & 1.9 & 2.8 & 1.3 & 1.8 & 2.9 & 1.5 & 2.2 & 4.8 & 0.013 \\
\hline Ferritin $(\mu \mathrm{g} / \mathrm{L})$ & 78 & 183 & 350 & 66 & 140 & 314 & 41 & 172 & 339 & 0.431 \\
\hline TfR-F Index & 0.6 & 0.9 & 1.3 & 0.6 & 0.8 & 1.4 & 0.7 & 1.0 & 2.5 & 0.049 \\
\hline Iron $(\mu \mathrm{mol} / \mathrm{L})$ & 19.5 & 27.4 & 38.1 & 17.6 & 25.3 & 37.0 & 10.9 & 25.5 & 41.5 & 0.903 \\
\hline Transferrin (g/L) & 1.57 & 1.84 & 2.44 & 1.45 & 2.00 & 2.53 & 1.63 & 2.06 & 2.98 & 0.154 \\
\hline TfSat $(\%)$ & 37 & 56 & 80 & 33 & 52 & 82 & 20 & 47 & 77 & 0.320 \\
\hline hsCRP (mg/L) & 0.09 & 0.10 & 0.25 & 0.09 & 0.09 & 0.19 & 0.09 & 0.14 & 0.50 & 0.045 \\
\hline
\end{tabular}

Abbreviations are explained in Table 2. $p$ value is the significance of the differences between the groups of newborns with normal $\mathrm{pH}$ and low $\mathrm{pH}$ using Mann-Whitney-U test.

Less iron may be incorporated in fetal RBCs, and therefore $\%$ HYPOm and \%HYPOr may increase and TfSat may decrease. However, in this study setting, we could not determine precisely whether the first step is reduced availability of iron alone, or with placental insufficiency at the same time.

We also studied the association between cellular indices and cord $\mathrm{pH}$ level, which is the most specific and rapid indicator of hypoxia intrapartum (34). A previous study has shown that EPO correlates strongly with cord blood $\mathrm{pH}$ or $\mathrm{PaO}_{2}$ (32). In the present study, the cell indices in newborns with low $\mathrm{pH}$ indicated lower hemoglobinization when compared with cells of newborns with normal $\mathrm{pH}$ or without signs of asphyxia. However, a limitation of this study is that although we have a considerable amount of $\mathrm{pH}$ results, we did not have $\mathrm{pH}$ results for newborns without clinical signs of birth asphyxia.

The stimulus for a rise in EPO occurs in adults within 1-2 h, depending on the severity of hypobaric hypoxia in humans (35). The half-life of EPO is about $5 \mathrm{~h}$. Therefore, EPO might also be raised because of prolonged or chronic impaired oxygen delivery (34). The $\mathrm{pH}$ value may change rapidly during delivery, and asphyxia develops when there is a discrepancy between oxygen supply and consumption. In this study we found that cord blood $\mathrm{pH}$, as an indicator of hypoxemia, also correlated with the indicators of increased iron-deficient erythropoiesis in newborns at birth. Therefore, the increased hypochromacy of the RBC (\%HYPOm, MCHC) and their precursors (\%HYPOr) in newborns might reflect lower reserves in the oxygenation and finally lowered $\mathrm{pH}$ values in newborns.

Low ferritin levels have been shown to be associated with high EPO levels in newborns of mothers not taking iron supplementation (36). Furthermore, low ferritin levels have been shown to be present in newborns whose mothers have diabetes mellitus or GDM $(33,37-39)$, and this has been found to be related to chronic intrauterine hypoxia (40). Even though we did not have pregnant women with DM in our study, we did have a few women with GDM. As in an earlier study (33) lower ferritin and higher MCV were also found in the newborns of GDM mothers, while the EPO and $\mathrm{pH}$ values were not different.

From the methodological point of view, it must be borne in mind that newborns typically have a great biologic variability in their analytes (23). This was also reflected in our results, with a wide range of measured values. Novel cell indices are nowadays available in the hematological analyzers produced by two manufacturers $(13,14,16)$. The RBC and reticulocyte indices have been established especially in screening the iron status in children and infants as well as in premenopausal women and in blood donors $(18,19,21,22)$. They are simple and cost-effective tools for screening the iron status, because they can be combined with the basic blood count without any need for other reagents. The particular advantage of cell indices is their ability to reveal changes in iron availability before anemia is manifested. However, the clinical usefulness of cell indices as specific indicators of iron-deficient erythropoiesis in newborns may be to some extent limited, since such indices may also be affected by accelerated erythropoiesis (23).

We also measured hsCRP, to exclude the influence of the acute phase response on the ferritin results. The question has also been raised whether the acute phase response may contribute to reticulocyte indices, since the blocking of iron in the 
macrophages decreases the iron availability in the hemoglobinization of newly formed RBCs. However, this was not the case in the present population, because all the cord blood hsCRP results of the newborns were low.

One further limitation of this study is that the population contained only a few $(n=9)$ iron-deficient newborns according to the definition of iron deficiency as TfSat $<30 \%$. This is why we could not perform a comprehensive and scientifically sound statistical analysis on the diagnostic accuracy of the cell indices as iron status markers in this population. Although we did not find many iron-deficient newborns, it is noteworthy that the association between cellular indices and $\mathrm{EPO}$ and $\mathrm{pH}$ was highly significant even within the physiologic range of the iron status. This, however, requires further study, investigating specific rare cases, and also studies focusing on high-risk pregnancies.

In conclusion, coordinated changes were observed in the $\mathrm{RBC}$ and reticulocyte indices and in EPO and $\mathrm{pH}$ in newborns at birth. Hence, reduced cellular $\mathrm{Hb}$ content might be a factor causing decreased tissue oxygenation, which is followed by a compensatory response of EPO production. The iron status of newborns measured by serum markers also correlated with changes in EPO and $\mathrm{pH}$. Therefore, further studies are warranted to establish whether the higher EPO concentration associated with iron deficiency is the cause of a poor neurologic outcome, and whether the poor outcome could be prevented by iron supplementation. The value of advanced cellular indices in the diagnostics of iron deficient erythropoiesis in neonatal period remains to be determined.

Acknowledgments. We thank the midwives at the Department of Obstetrics in Kuopio University Hospital who helped us to collect the samples. We owe special thanks to Ms. Raija Isomäki and the other laboratory technicians at the Laboratory Centre for performing the analyses.

\section{REFERENCES}

1. Ratcliffe PJ 2002 From erythropoietin to oxygen: hypoxia-inducible factor hydroxylases and the hypoxia signal pathway. Blood Purif 20:445-450

2. Lee JW, Bae SH, Jeong JW, Kim SH, Kim KW 2004 Hypoxia-inducible factor (HIF-1) $\alpha$ : its protein stability and biological functions. Exp Mol Med 36:1-12

3. Davis LE, Widness JA, Brace RA 2003 Renal and placental secretion of erythropoietin during anemia or hypoxia in the ovine fetus. Am J Obstet Gynecol 189:1764-1770

4. Yu X, Shacka JJ, Eells JB, Suarez-Quian C, Przygodzki RM, Beleslin-Cokic B, Lin C-S, Nikodem VM, Hempstead B, Flanders KC, Costantini F, Noguchi CT 2002 Erythropoietin receptor signalling is required for normal brain development. Development 129:505-516

5. Juul SE 2000 Nonerythropoietic roles of erythropoietin in the fetus and neonate. Clin Perinatol 27:527-541

6. Sirén A-L, Fratelli M, Brines M, Goemans C, Casagrande S, Lewczuk P, Keenan S, Gleiter C, Pasquali C, Capobianco A, Mennini T, Heumann R, Cerami A, Ehrenreich H, Ghezzi P 2001 Erythropoietin prevents neuronal apoptosis after cerebral ischemia and metabolic stress. Proc Natl Acad Sci USA 98:4044-4049

7. Ehrenreich H, Aust C, Krampe H, Jahn H, Jacob S, Herrmann M, Sirén A-L 2004 Erythropoietin: novel approaches to neuroprotection in human brain disease. Metab Brain Dis 19:195-206

8. Ruth V, Autti-Rämö I, Granström M-L, Korkman M, Raivio KO 1988 Prediction of perinatal brain damage by cord plasma vasopression, erythropoietin, and hypoxanthine values. J Pediatr 113:880-885

9. Lozoff B, Georgieff MK 2006 Iron deficiency and brain development. Semin Pediatr Neurol 13:158-165

10. Tamura T, Goldenberg R, Hou J, Johnston K, Cliver S, Ramey S, Nelson K 2002 Cord serum ferritin concentrations and mental and psychomotor development of children at five years of age. J Pediatr 140:165-170
11. Rao R, Georgieff MK 2002 Perinatal aspects of iron metabolism. Acta Paediatr Suppl 91:124-129

12. Kotisaari S, Romppanen J, Penttilä I, Punnonen K 2002 The Advia 120 red blood cell and reticulocyte indices are useful in diagnosis of iron-deficiency anemia. Eur J Haematol 68:150-156

13. Brugnara C, Schiller B, Moran J 2006 Reticulocyte hemoglobin equivalent (Ret He) and assessment of iron-deficient states. Clin Lab Haematol 28:303-308

14. Thomas L, Franck S, Messinger M, Linssen J, Thomé M, Thomas C 2005 Reticulocyte hemoglobin measurement-comparison of two methods in the diagnosis of iron-restricted erythropoiesis. Clin Chem Lab Med 43:1193-1202

15. d'Onofrio G, Chirillo R, Zini G, Caenaro G, Tommasi M, Micciulli G 1995 Simultaneous measurement of reticulocyte and red blood cell indices in healthy subjects and patients with microcytic and macrocytic anemia. Blood 85:818-823

16. Mohandas N, Kim YR, Tycko DH, Orlik J, Wyatt J, Groner W 1986 Accurate and independent measurement of volume and hemoglobin concentration of individual red cells by laser light scattering. Blood 68:506-513

17. Fishbane S, Shapiro W, Dutka P, Valenzuela OF, Faubert J 2001 A randomized trial of iron deficiency testing strategies in hemodialysis patients. Kidney Int 60:2406-2411

18. Brugnara C, Zurakowski D, DiCanzio J, Boyd T, Platt O 1999 Reticulocyte hemoglobin content to diagnose iron deficiency in children. JAMA 281:2225-2230

19. Ullrich $\mathrm{C}$, Wu A, Armsby C, Rieber S, Wingerter S, Brugnara C, Shapiro D, Bernstein H 2005 Screening healthy infants for iron deficiency using reticulocyte hemoglobin content. JAMA 294:924-930

20. Stoffman N, Brugnara C, Woods ER 2005 An algorithm using reticulocyte hemoglobin content $(\mathrm{CHr})$ measurement in screening adolescent for iron deficiency. J Adolesc Health 36:529

21. Luo D, Chen Y, Wu W, Zhang F, Xu J, Cui W, Li S, Li R 2007 Reticulocyte hemoglobin content in diagnosis of iron deficiency in Chinese pre-menopausal women. Chin Med J (Engl) 120:1010-1012

22. Radtke H, Meyer T, Kalus U, Röcker L, Salama A, Kiesewetter H, Latza R 2005 Rapid identification of iron deficiency in blood donors with red cell indexes provided by Advia 120 . Transfusion 45:5-10

23. Ervasti M, Kotisaari S, Sankilampi U, Heinonen S, Punnonen K 2007 The relationship between red blood cell and reticulocyte indices and serum markers of iron status in the cord blood of newborns. Clin Chem Lab Med 45:1000-1003

24. Ervasti M, Kotisaari S, Heinonen S, Punnonen K 2008 Elevated serum erythropoietin concentration is associated with coordinated changes in red blood cell and reticulocyte indices of pregnant women at term. Scand J Clin Lab Invest 68:160-165

25. Ervasti M, Kotisaari S, Heinonen S, Punnonen K 2007 Use of advanced red blood cell and reticulocyte indices improves the accuracy in diagnosing iron deficiency in pregnant women at term. Eur J Haematol 79:539-545

26. Heinonen S, Saarikoski S 2001 Reproductive risk factors of fetal asphyxia at delivery: a population based analysis. J Clin Epidemiol 54:407-410

27. Nathan DG, Oski FA 1993 Hematology of Infancy and Childhood. Philadelphia: Saunders, p Appendix ii

28. Widness JA, Clemons GK, Garcia JF, Oh W, Schwartz R 1984 Increased immunoreactive erythropoietin in cord serum after labor. Am J Obstet Gynecol 148:194-197

29. Fahnenstich H, Dame C, Alléra A, Kowalewski S 1996 Biochemical monitoring of fetal distress with serum-immunoreactive erythropoietin. J Perinat Med 24:85-91

30. Moya FR, Grannum PA, Widness JA, Clemons GK, Copel JA, Hobbins JC 1993 Erythropoietin in human fetuses with immune hemolytic anemia and hydrops fetalis. Obstet Gynecol 82:353-358

31. Voutilainen PE, Widness JA, Clemons GK, Schwartz R, Teramo KA 1989 Amniotic fluid erythropoietin predicts fetal distress in Rh-immunized pregnancies. Am J Obstet Gynecol 160:429-434

32. Rollins MD, Maxwell AP, Afrasiabi M, Halliday HL, Lappin TR 1993 Cord blood erythropoietin, $\mathrm{pH}, \mathrm{PaO} 2$ and haematocrit following caesarean section before labour. Biol Neonate 63:147-152

33. Lott DG, Zimmerman MB, Labbé RF, Kling PJ, Widness JA 2005 Erythrocyte zinc protoporphyrin is elevated with prematurity and fetal hypoxemia. Pediatrics 116:414-422

34. Maier RF, Böhme K, Dudenhausen JW, Obladen M 1993 Cord blood erythropoietin in relation to different markers of fetal hypoxia. Obstet Gynecol 81:575-580

35. Eckardt K-U, Boutellier U, Kurtz A, Schopen M, Koller E, Bauer C 1989 Rate of erythropoietin formation in humans in response to acute hypobaric hypoxia. J Appl Physiol 66:1785-1788

36. Milman N, Graudal N, Nielsen OJ, Agger AO 1996 Cord serum erythropoietin in 90 healthy newborn term infants: relationship to blood gases and iron status markers. Int J Hematol 64:197-201

37. Chockalingam UM, Murphy E, Ophoven JC, Weisdorf SA, Georgieff MK 1987 Cord transferrin and ferritin values in newborn infants at risk for prenatal uteroplacental insufficiency and chronic hypoxia. J Pediatr 111:283-286

38. Verner AM, Manderson J, Lappin TR, McCance DR, Halliday HL, Sweet DG 2007 Influence of maternal diabetes mellitus on fetal iron status. Arch Dis Child Fetal Neonatal Ed 92:F399-F401

39. Petry CD, Wobken JD, McKay H, Eaton MA, Seybold VS, Johnson DE, Georgieff MK 1994 Placental transferrin receptor in diabetic pregnancies with increased fetal iron demand. Am J Physiol 267:E507-E514

40. Schwartz R, Teramo KA 2000 Effects of diabetic pregnancy on the fetus and newborn. Semin Perinatol 24:120-135 